\title{
意味と親和性のある統語構造を出力する日本語文パーザ
}

\author{
武本裕 ${ }^{\dagger}$ 宮崎 正弘 $^{\dagger}$
}

英語に比べて語順が自由で省略の多い日本語は, 句構造解析には不向きとされ，係 り受け解析が一般的となっている。また，係り受けが交差する入れ子破りが起こる 表現や二つの品詞性のある語などは, 句構造解析による木構造ではうまく扱えない. さらに, 現在主流となっている文節構文論 (学校文法) に基づく構文解析では構文 解析結果が意味と整合性が良くなく, 時枝文法風の構文解析の方が解析結果に則っ て意味がうまく説明できることが指摘されている，本論文では，時枝によって提唱 された言語過程説を発展的に継承した三浦の言語モデル（関係意味論に基づく三浦 の入れ子構造）とそれらの基づく日本語文法体系（三浦文法）による文法記述と文 法規則適用条件の制御によって上記のような日本語構文解析上の問題を解決する方 法を提案する。さらに，このような考えに基づき試作した日本語文パーザによって， 一対多·多対一の係り受け関係，文中の局所的入れ子構造，入れ子破りの表現，主 題の「は」と対照の「は」の扱い，二つの品詞性のある語の扱いにおいて意味的に 適切な統語構造が得られることを示した。

キーワード: 構文解析, 言語過程説, 三浦文法

\section{Japanese Parser Generating Suitable Syntactic Structures for Meaning}

\author{
YUTAKA TAKEMOTO ${ }^{\dagger}$ and MASAHIRo MIYAZAKI ${ }^{\dagger}$
}

Japanese is a free word order language and ellipsis frequently occur compared with English. Japanese sentences are not suitable to be parsed by the phrase structure analysis and is generally parsed by the dependency analysis. Tree structures by the phrase structure analysis does not describe well in expressions with crossed dependencies and in words with duality of parts of speech. The major syntactic analysis based on Japanese school grammar does not generate suitable syntactic structures for meaning. In contrast with this situation, a syntactic analysis based on Tokieda grammar can explain meaning of Japanese sentences well. Miura grammar is a Japanese grammar on the Constructive Process Theory proposed by M. Tokieda, and developed by T. Miura. This paper proposes a solution to the above problems in Japanese Syntactic Analysis by grammar descriptions based on Miura language model and Miura grammar, and by controls of grammar application. A trial parser based on the ideas generates suitable syntactic structures for meaning, in one-to- $\mathrm{N}$ or $\mathrm{N}$-to-one dependency relations, in local nest in sentences, in distinction between topic marker "ha" and contrast marker "ha" in Japanese particle "ha", and in words with duality of parts of speech.

†新潟大学大学院自然科学研究科, Graduate school of science and technology, Niigata University 
Key Words: syntactic analysis, the Constructive Process Theory, Miura grammar

\section{1 まえがき}

人間の言語能力をコンピュータ上に実現することを狙った自然言語処理については，近年盛 んに研究されている。しかし，かな漢字変換方式の日本語ワープロのように実用システムとし て成功した例はまれで，多くは実験システムの域にとどまっている．実際，自然言語の壁は厚 く, 多くの研究者が従来の言語理論と実際の自然言語との間にギャップがあると感じている. 事実，従来の計算言語学は強化されてきたとはいえ，自然言語の持つ論理的な一傾面しか説明 できず，現実の言語に十分に対応できていない.

英語に比べて語順が自由で省略の多い日本語は, 句構造解析には不向きとされ, 係り受け解 析が一般的となっている．また，係り受けが交差する入れ子破りが起こる表現は，係り受け解 析では扱えるが, 句構造解析による木構造では扱えない, さらに, 文内で独自の統語・意味構 造をもつ複合名詞や名詞句は，これらに適した個別的な構造解析法を模索する必要がある.

現在, 主流となっている文節構文論（学校文法）に基づく構文解析では以下の例に示すよう に構文解析結果が意味と整合性が良くなく, 時枝文法風の構文解析の方が解析結果に則って意 味がうまく説明できることが指摘されている(水谷 1993) .

・「梅の花が咲く.」

この文は「梅の／花が／咲く.」と文節に分割でき，係り受け解析では，「梅の」が「花 が」に係り，「花が」が「咲く」に係るが，図１に示すように「梅の」は「花」のみに係 ることが望ましい.

・「山を下り，村に着いた.」

この文は「山を/下り／村に／着いた.」と文節に分割でき，係り受け解析では，「山を」 が「下り」に，「下り」が「着いた」に，「村に」が「着いた」に係るが，図 2 に示すよう に「下り」と「着い」をともに「た」が受けることが望ましい。

- 「魚を鈞りに行く.」

この文は「魚を/釣りに/行く.」と分割でき，係り受け解析では，「魚を」が「釣りに」 に係り，「釣りに」が「行く」に係るが，図3に示すように「魚を」は「釣り」のみに係 ることが望ましい．この際，「釣り」が連用形名詞であり，名詞と動詞の品詞の二重性を もつことに注意が必要である。

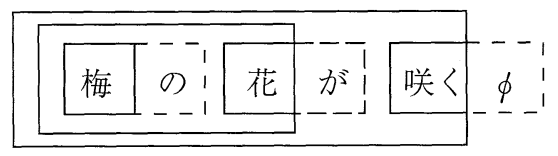

図 1 「梅の花が咲く.」の入れ子構造 


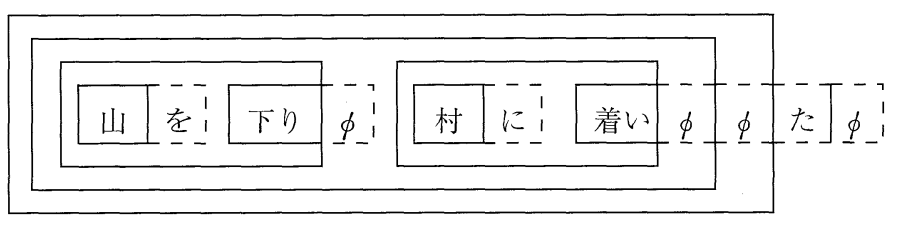

図 2 「山を下り，村に着いた.」の入れ子構造

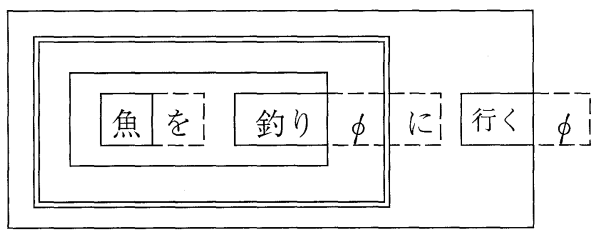

図 3 「魚を釣りに行く.」の入れ子構造

元来, 構文解析は文の意味を正しく解析するために行うのであるから，日本語文パーザには 意味と親和性のある統語構造を出力することが要求される.

日本語文解析全体としては, 形態素解析に始まり, 構文解析, 意味解析と続く流れを想定し ている.ここで, 構文解析と意味解析は分離しているが, 構文解析は意味解析を助ける構造を 出力することが求められる。すなわち, 助詞・助動詞などの機能語, 形式名詞から作り出され る文の骨格，いわば構造が持つ意味を的確に捕らえておくことが必要である.

構文解析そのものは，意味情報を導入することにより多義が発生することを避け，表層的情 報・統語的情報のみを用いて解析するものとする。この方針は，長尾 (長尾眞 1996)の「文は何 らかの新しい情報（知識）を伝えるものであるから，文の構造を理解するために前もって意味 的な情報が必要であると仮定することには本質的に問題がある。たとえば未知の分野の専門書 などを読む場合，その内容 (意味) は文の構造から理解できるという状況が考えられる.」との 見解とも一致する.

従来から日本語構文解析の主流となっている, 係り受け解析に基づく $\mathrm{KNP}$ (黒橋, 長尾 1994) が既に作成されており，句棈造の流れをくむHPSGを用いた日本語文解析についての研究 (大 谷, 宮田，松本 2000) なども行われている。係り受け解析との対比は以降の章で詳細を述べる. 上記の HPSG 関連の研究は, 主に日本語単文を HPSG で取り扱う上での問題点とその解決策に ついて示したものであり，単文だけでなく，複文，重文などを対象とし，語の単位と機能を整 理し直した構文解析の体系を作り出そうとしている本研究の目標と異なるものである。さらに, 本論文で提案するパーザでは構文解析と意味解析を分離しており，HPSGのように構文解析と 意味解析と融合するのではないため，本論文では特に比較を行わない.

本論文では，上記のような日本語構文解析上の問題を解決するものとして，従来の研究では 見逃されていた言語の過程的構造 (池原, 宮崎, 白井, 林 1987; 池原, 宮崎, 白井 1992; 宮崎, 
池原, 白井 1992）に目を向け，三浦の言語モデル（関係意味論に基づく三浦の入れ子構造）と それらの基づく日本語文法体系（三浦文法）をベースにした意味と親和性のある統語構造を出 力する日本語文パーザの枠組みを提案し，その有効性について論じる.

最後に，本論文中で意味との整合性が良くないとして取り上げたパターンの出現頻度が低く ないこと抢よびパーザが最低限の解析能力を持つことを実験により検証する.

\section{2 三浦の言語モデルによる文の基本構造}

\section{1 言語過程説と三浦の関係意味論}

時枝誠記が提唱し，三浦つとむが発展的に継承した言語過程説によれば，言語表現には万人 に共通する対象のあり方がそのまま表現されているのではなく, 対象のあり方が話者の認識（対 象の見方, 捉え方, 話者の感情・意志・判断などの対象に立ち向かう話者の心的状況）を通し て，言語に関する約束事である言語規範（文法，単語の語義・用法など）に従って表現されて いる.このように対象一認識一表現の過程を辿ることによって言語表現を生成する過程が言語 生成である (図 4 参照). 聞き手 (読者) が話者（書き手）の言語生成の過程を逆に辿り，言語 規範を手がかりに言語表現と話者の認識を対応づけ，聞き手が話者に同化し話者の認識を追体 験し, 自己の頭の中に話者の認識を再構成し, 対象のあり方を推論する過程が言語理解である (図 4 参照)。言語表現には，概念化された対象の姿を表す客体的表現と主体（話者）の対象に 関する感情・意志・判断などを直接表した主体表現があり，言語理解において，これらを区別 して扱うことが重要である。

時枝の言語過程説，およびそれに基づく日本語文法体系（時枝文法）(時枝誠記 1941，1950) を発展的に継承した三浦は，時枝が指摘した主体的表現と客体的表現の言語表現上の違いなど を継承しつつ，時枝が言語の意味を主体的意味作用（主体が対象を認識する仕方）として, 話 者の活動そのものに求めていたのを排し，意味は表現自体がもっている客観的な関係（言語規 範によって表現に固定された対象と認識の関係) であるとした関係意味論 (三浦つとむ 1977; 池 原 1991) を提唱し，それに基づく新しい日本語文法，三浦文法 (三浦つとむ 1967a, 1967b, 1972，

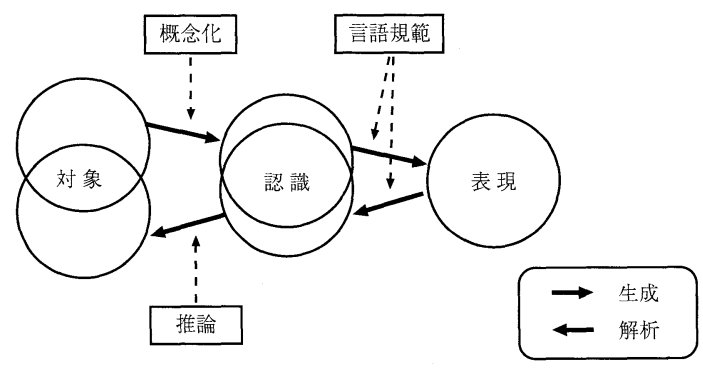

図 4 言語の過程的構造 
1975, 1976) を提案している.

三浦の意味論によれば，言語の意味は表現に結び付き固定された対象と認識の関係であるが， 対象は直接表現に結合されるのではなく, 話者の目を通して得られた認識が表現に結合される のであるから，より限定的に捉え，表現と認識の関係を意味と考える.コンピュータでは，関 係はポインターで表現されるため，表現と話者の認識を対応付けるポインターが意味であり， このようなポインターを張ることが意味解析であるといえる，意味処理には，話者が言語表現 に使用した意味上の約束を特定する意味解析と表現内容を把握（追体験）する意味理解の $2 つ$ のステップがある。意味解析では, 辞書上の意味（言語上の約束）の中から表現上の意味（実 際に使われた約束）を判定する。意味理解では，特定された約束と聞き手が話者と共通しても つ世界知識を手がかりに聞き手のもつ世界モデルと対応づけ，話者の認識した世界（認識構造） を再現する。

\section{2 三浦の入れ子構造}

時枝によれば，言語表現は以下のように主体的表現（辞）と客体的表現（詞）に分けられ，文 は，辞が詞を包み込むようにして構成された句を，別の句が重層的に包み込んだ入れ子型構造 (図 5 参照) で表される。

- 主体的表現: 話者の主観的な感情, 要求, 意志, 判断などを直接表現したものであり, 日 本語では, 助詞, 助動詞（陳述を表す零記号, すなわち困 5 に示すように肯定判断を表 すが，表現としては省略された助動詞を含む)，感動詞，接続詞，陳述副詞で表される。

- 客体的表現：話者が対象を概念化して捉えた表現で, 日本語では, 名詞, 動詞, 形容詞, 副詞，連体詞，接辞で表される。主観的な感情や意志などであっても，それが話者の対 象として捉えられたものであれば概念化し，客体的表現として表される.

時枝は「私が読んだ」などの文における代名詞「私」は, 主体そのものでなく, 主体が客体 化されたものであるという“主体の客体化”の問題を提起した。これを対象の認識の立場から発 展させ，主体の観念的自己分裂と視点の移動という観点から言語表現を捉えたのは三浦である.

三浦は，一人称の表現は見たところ，自分と話者が同一の人間であるが，これを対象として 捉えていると言うことは，対象から独立して対象に立ち向かっている人間が存在していること であるとして，対象に立ち向かっている人間は別の人間であるとしているすなわち，一人称

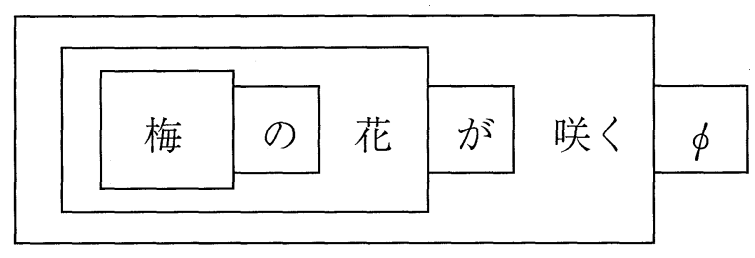

図 5 時枝の入れ子構造 
の場合には現実には同一の人間であるように見えても，実は観念的な自己分裂によって観念的 な話者が生まれ，この自己分裂した自分と対象になっている自分との関係が一人称として表現 されると考えるのである。

話者と話者自身の関係は，上記のような認識の構造において成立するものであるが，同様の 関係が過去や未来を表現する時制の表現，否定表現などでも見られる．話者自身が対象となっ ていない場合でも，自己分裂した話者は過去や未来の世界に入って行き，対象との関係を現在 形で捉えた後，現在の世界に戻って来ると考えるのである。また，否定表現では否定する対象 が必要であるが，否定するのであるから現実世界にはその対象がない，そこで，対象が否定さ れないような仮想世界に自己分裂した話者が入り込み，対象に対し肯定判断をした後，現実世 界で否定判断を行うといったネストした世界構造で否定を捉えるのである。三浦は，このよう な観念的な話者による視点の移動を表すものとして, 観念的世界が多重化した入れ子構造の世 界の中を自己分裂によって生じた観念的話者が移動する入れ子構造モデル（図 6 参照）を提案 している，現在の否定表現や過去の表現は，それぞれ (現在の仮想世界／現在の現実世界)，(過 去の現実世界／現在の現実世界）の二重の入れ子構造となる。また，過去の否定表現は，（過去 の仮想世界／過去の現実世界／現在の現実世界）の三重の入れ子構造となる。さらに，過去の 否定推量表現は, (他の人の過去の仮想世界／他の人の過去の現実世界／他の人の現在の現実世 界／話者の現在の現実世界）の四重の入れ子構造となる.

三浦の提唱する言語の過程的構造を図 7 に示す.

\section{3 文の基本構造}

日本語は, 膠着言語に分類される言語であり, 小さな単位要素が次々と付着して表現を形成し ていくという特徵を持つ。これらの単位要素が結合し, 表現構造を形成していく過程には一定

[客体的表現]

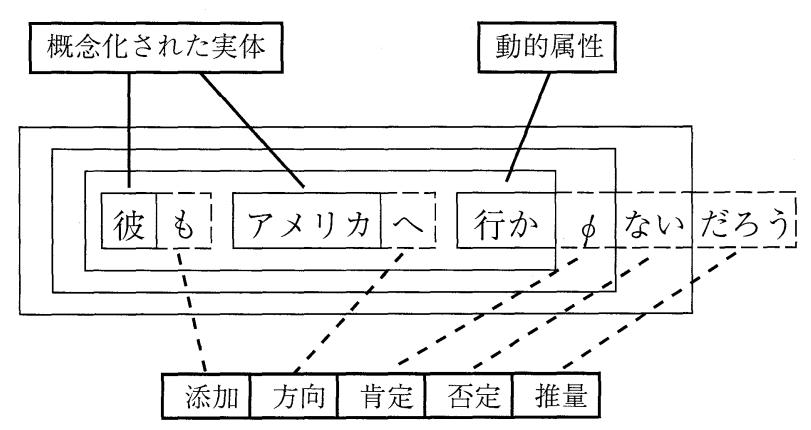

[主体的表現]

図 6 三浦の入れ子構造 


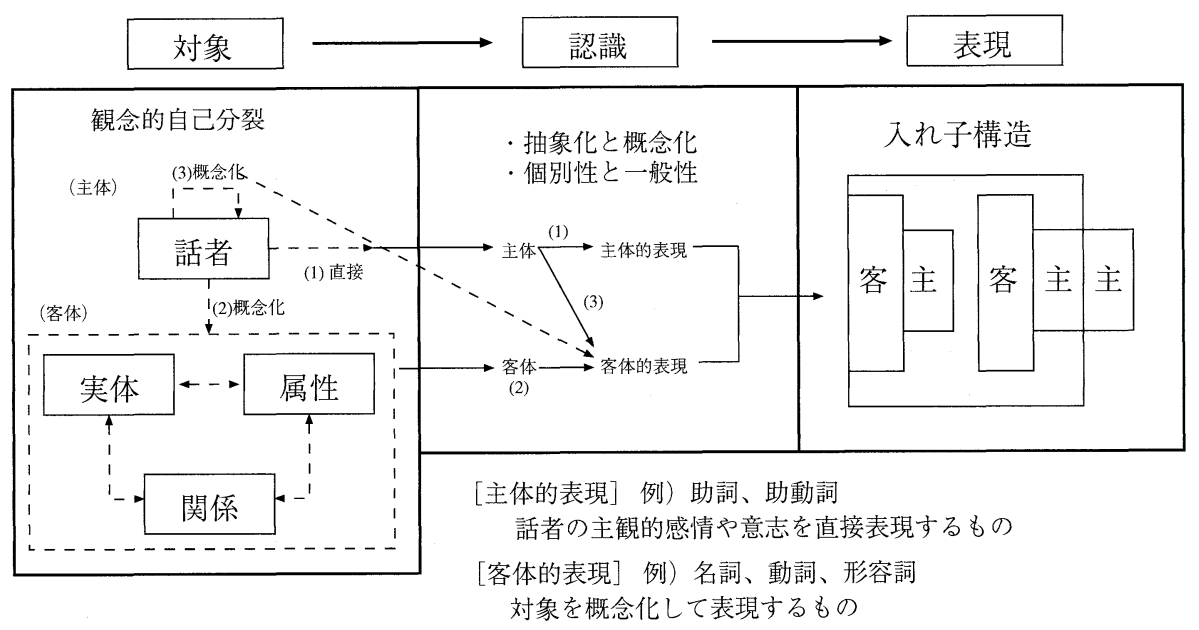

図 7 三浦の言語モデル

の手順がある。言語過程説によれば，日本語の表現は客体的表現と主体的表現が入れ子になっ た構造として捉えることができる。

ここで，表現の元となる対象世界を構成する一つの事象は，実体・属性・関係の 3 要素から 構成される。これらに対する話者の認識を言語規範を介して表現に結び付けるときに最も基本 となるのは，概念化された対象（実体・属性・関係）とそれを表現する単語（詞）との対応関 係，ならびに概念化された対象に対する話者自身（主体）のあり方と単語（辞）との関係であ る. 前者に対して詞が選択され，後者においてそれに辞が付加される.このようにして概念化 された対象および主体と単語との結び付きが形成されると, 次にそれらの相互関係が構造化さ れ, 認識された構造と表現構造との対応付けが行われる.この過程で単語と単語が統語規則に 従って構造化され，文が形成される(池原，白井 1990).

\section{3 三浦文法に基づく日本語品詞体系}

三浦文法では他の多くの文法とは異なり，表現に用いられる単語を文構成上の機能や単語が 表す内容で分類するのではなく，対象の種類とその捉え方で分類する. 三浦文法に基づく品詞 分類の基本的考え方, それに基づき作成された日本語の品詞体系の詳細については(宮崎, 白井, 池原 1995) に述べられているので，ここでは従来の学校文法との主な相違点のみ述べておく.

三浦文法に基づく品詞体系と学校文法との主要な相違点は, 以下の通りである (宮崎他 1995).

（1）形容動詞を独立した品詞とはせず, 名詞（静詞）十助動詞（肯定判断）「だ」/名詞（静 詞）十格助詞「に」とした。

（2）受身・使役の助動詞（れる，られる，せる，させる）は動的属性を付与する詞とし，動 
詞型接尾辞とした。

（3）希望の助動詞（たい）は静的属性を付与する詞とし，形容詞型接尾辞とした.

（4）伝聞の助動詞（そうだ），比況の助動詞（ようだ），様相の助動詞（そうだ）は助動詞と せず，それぞれ，形式名詞（そう，よう）／静詞型接尾辞（そう）＋肯定判断の助動詞 (だ）とした。

（5）準体助詞（の），終助詞（の）は形式名詞とした.

(6) 接続助詞 (ので, のに), 終助詞 (のだ) はそれぞれ, 形式名詞（の）+[格助詞（で）／ 肯定判断の助動詞（だ）の連用形 1（で）]／格助詞（に）／肯定判断の助動詞（だ）と した。

（7）接続助詞（て，で，たり，だり）は既定判断の助動詞（た，だ）の連用形 1 とした.

（8）補助動詞（ある），補助形容詞（ない）はそれぞれ，肯定判断の助動詞，否定判断の助動 詞とした。

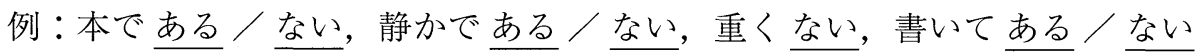

(9) 既定判断の助動詞の連用形 1 （て，で）に後接する動詞（いる，みる，くれる，あげる， くる，もらう，やる，しまう，おく，いく，下さる，いただく，‥)，形容詞連用形 1 人 [静詞十格助詞（に）] に後接する動詞（する，なる），およびサ変動詞型名詞／連用形名 詞に後接する動詞（する，できる，下さる，なさる，致す，申す，申し上げる，いたた く，願う，たまう，‥) は，形式動詞とする.

例：走っている，美しくなる，静かになる，開発する

(10) 動詞, 形容詞, 動詞型接尾辞, 形容詞型接尾辞のような活用語の活用形は, 従来の学校 文法における 6 活用形を基本とし，以下の変更を加えた(宮崎他 1995).

未然形を以下の 2 通りに細分化した。

- 未然形 1 : 推量形 [〜う，〜よう]

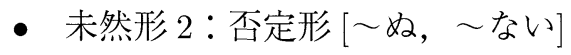

連用形を以下の 3 通りに細分化した。

- 連用中止形 $[\sim, \sim ま す] \cdot$ 連用修飾形

- イ音便形 /促音便形 /撥音便形 [〜た，〜だ]

・形容しウ音便形 [〜ございます] ・動詞ウ音便形 [〜た，〜だ

形容詞のカリ活用語尾は以下のように扱う.

- かろ (未然形 1) $\rightarrow$

く（形容詞語尾・連用形 $1 ）+$ あ (助動詞「ある」の未然形 1$)$

- 加（連用形 2) $\rightarrow$

く（形容詞語尾・連用形 $1 ）+$ あっ（助動詞「ある」の連用形 2$)$

タルト型形容動詞活用語尾は，以下のように扱う。 
- と (連用形 1) $\rightarrow$ と（格助詞 $)$

・ たる (連体形 $) \rightarrow$ と (格助詞 $)+$ あ (形式動詞「ある」の連体形)

\section{4 意味と整合性のよい構文解析}

意味は表現と認識，対象の結びつきであるという観点に立てば，構文は対象を捉える枠組み であると考えられる．枠組みは対象の捉え方を立体化して表現するための構造体である．単語， 句，節，文など，対象のあり方と認識のしかたに応じてそれを表現する枠組みも種々存在する。

言語表現の解析では，与えられた表現がどのような枠組みで表現されたものか，またその枠 組みはどのような認識構造を表す規則を手がかりに，実際はどんな意味で使われているかを明 らかにする必要がある。いわゆる，構文解析は言語表現の統語構造を明らかにする過程であり， 表現の入れ子構造を捉え，それぞれの要素間の関係を明らかにすることである.

三浦文法による日本語品詞体系 (宮崎他 1995) は, 構文構造として, 従来の句構造や係り受け 構造とは異なった三浦の入れ子構造を想定しており, 三浦の言語モデルと親和性がよい. 三浦 文法は時枝文法を発展的に継承しており，意味と整合性のよい日本語文パーザの実現が期待で きる。

ここで, 工学的には三浦の入れ子構造をコンピュータ内に実現する枠組みとして, 句構造解 析風の木構造を用いる. 以下, 従来の句構造解析とは異なる, 三浦の入れ子構造に基づく意味 的にも正しい解析木を得るため, 文法規則の記述や文法規則の適用条件の制御をどのように行 うかについて述べる。

本章では, 構文構造が表す意味という観点から以下の 4 点の意味と整合性の良くないパター ンについて示した. 構文構造が表す意味とは, 助詞・助動詞などの機能語, 形式名詞から作り 出される枠組みを想定している，そして，文は単文という基本的な構造をべースとして，これ を接続，埋め込みという仕組みにより，単文相当の節を組み合わせてさらに複雑な構造（重文・ 複文）を作り出している.

このように単文からボトムアップに組み上げていく仕組みと機能語・形式名詞による枠組み という観点から 4 点の意味と整合性の良くないパターンを取り上げた. 現時点ではこのパター ンに網羅性があると考える。また, 水谷 (水谷 1993) は形容動詞の活用語尾，助動詞「〜た」の 分配法則的な広がりを持つスコープ，係り受け交差について言及しており，これも参考にして いる.この網羅性の実験的な検証は 5.2 節にて示す.

\section{1 一対多・多対一の係り受け関係}

「山を下り，村に着いた」は，学校文法風に解析すれば，図 8(a)のような意味的におかしい解 析結果を得るが，三浦文法風に解析すれば，図 8(b) のように意味的に正しい解析ができる[助 
動詞「た」の受けの範囲（スコープ）は，(b) の場合動詞「下る」と「着く」を含む文全体とな るが，(a)の場合動詞「着く」のみとなる].

また，「太郎は今日山を下り，村に着いた」は，学校文法風の係り受け解析では，図 8(c) のよ うに「太郎は」「今日」の係り先は「下り」か「着いた」のどちらか一方となる゙（通常，係り 受け解析では係り受けの曖昧さの爆発的増大を抑止するため, 係り受けの非交差条件と係り先 は 1 つであるという制約をもうけている)，三浦文法風に解析すれば，図 $8(\mathrm{~d})$ のように「太郎 は」「今日」が共に「下り」「着い」の両方に係っているという意味的にも正しい解析結果を入 れ子構造により自然に表現することができる（助動詞「た」のスコープは，(d)の場合動詞「下 る」と「着く」を含む文全体となるが，(c)の場合動詞「着く」のみとなる).

三浦文法に基づく文法規則，および日本語文パーザにおける文法規則の適用条件の制御など によって, 従来の句構造解析と異なる，意味的にも正しい解析木を得ることができる。図 8 の (b)，および (d) の入れ子構造に対応する解析木を図 $9(\mathrm{a})$ と (b) に示す.

(a) 学校文法風の解析結果

$$
\text { (（（山を）（下り））（（村に）（着いた）） }
$$

(b) 三浦文法風の解析結果

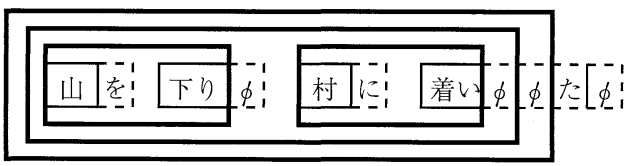

(c) 学校文法風の係り受け解析結果

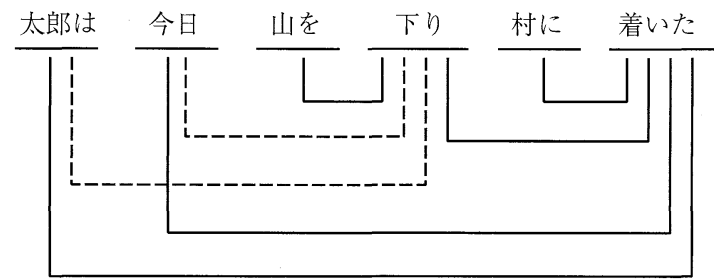

(d) 三浦文法風の解析結果

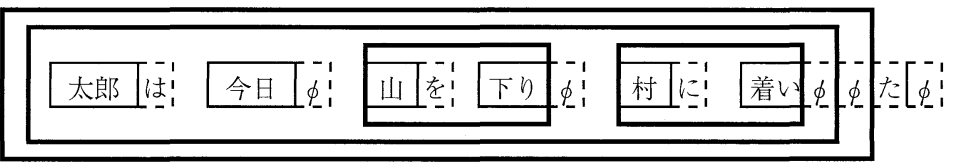

図 8 構文解析結果と意味との整合性 
(a)

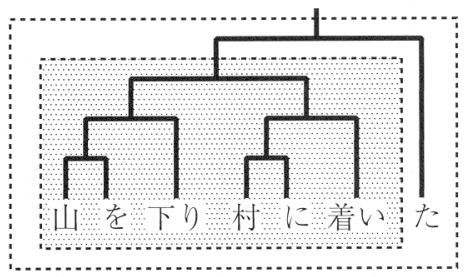

(b)

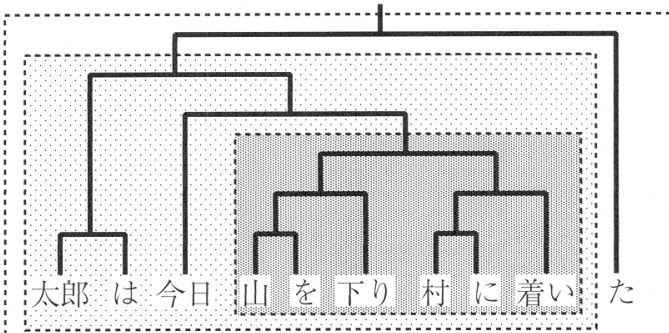

図 9 意味と整合性のよい解析木

\section{2 主題の「は」と対照の「は」の扱い}

係助詞・副助詞「は」には，「〜は」の係りの範井（スコープ）が異なる，構文構造に大きな 差異を生じさせる用法（主題の「は」と対照の「は」）がある(沼崎，宮崎 1995)。例えば，「彼 は金は無いが，アイデアはたくさん持っていた」では，上記の 2 種類の「は」が使われている。

「彼は」の「は」はいわゆる主題の「は」であり，広いスコープをもち，「金は無いが，アイ デアはたくさん持ってい」全体に係る。「金は」「アイデアは」の「は」は，対で用いられる対 照の「は」であり，それぞれ対となる部分に限定して係る。「金は」は「無い」に倸り，「アイ デアは」は「たくさん持ってい」にのみ係る。このように，「は」は用法によりスコープが異な るため，これを区別する処理を日本語パーザに導入することで，例に示した文では，図 10 に示 すような解析木を出力できる。

\section{3 文中に局所的な入れ子構造をもつ文}

\subsection{1 二つの品詞性のある語の扱い}

一語が二つの品詞性を持つ場合（一語が体と用を兼ねて使われる場合等）の例として「魚を

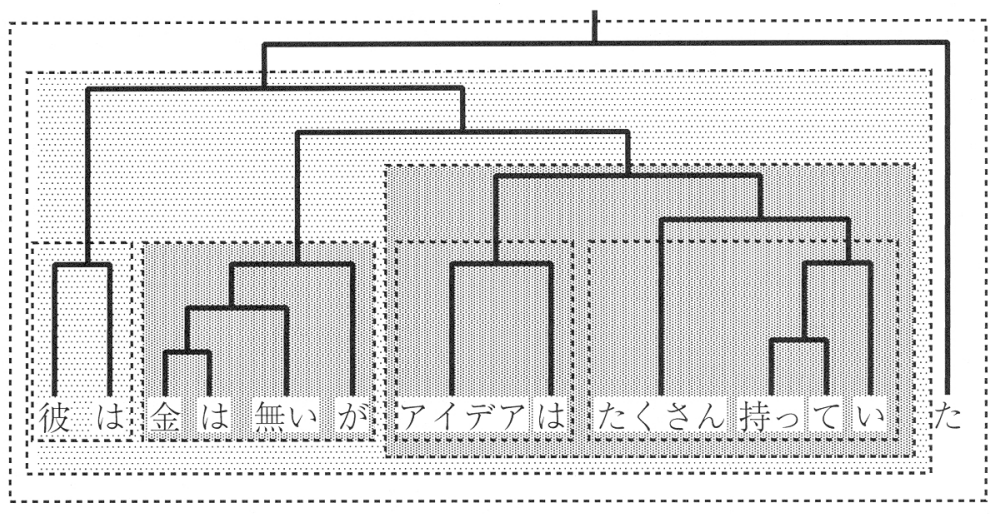

図 102 種類の「は」を含む文の入れ子構造 
(a)

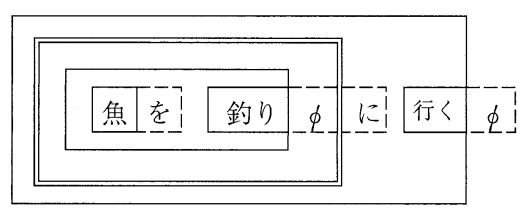

(b)

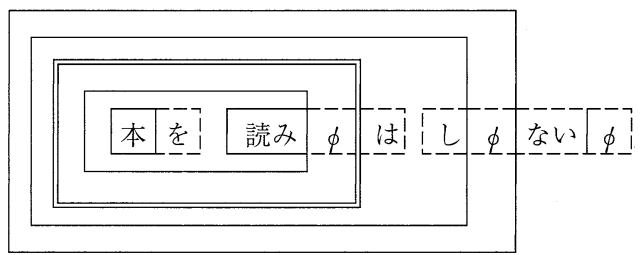

図 11 二つの品詞性のある語を含む文の入れ子構造

釣りに行く」という文をとりあげる。この表現は図 11(a)のような入れ子構造と見ることがで きる．「釣り」は二重線の内側の世界では「魚を」という格要素をとる動詞「釣り」として働い ているが，その外側の世界では局所的な文「魚を釣り」全体を実体化（名詞化）したうえで，格 助詞「に」に接続して，動詞「行く」の格要素を構成している.

「本を読みはしない」という文では，話者は「本を読む」という事象を取り上げ，「は」で特殊 性という主体判断を下した後，その動作に対して否定の判断を下している（(沼崎, 宮崎 1995) を参照)。ここで, 事象の特殊性を表すために, 取り上げた事象全体の捉え直しも行われ, 実体 化（体言化）が行われている。すなわち，この表現は図 11(b) のような入れ子構造と見ること ができる，「読む」は二重線の内側の世界では動詞として働いているが，その外の世界の構成要 素で体言の一部分を構成していると考えられる。このように, 実際の表現の場面では, ある品 詞属性を持つ単語が組み合わさって文要素が構成されるという単純な図式では説明できないも のを図 11(a)〜 (b) のように入れ子構造によって自然に扱うことができる。「うなぎを食べに浜 松に行く」の解析木を図 $12(\mathrm{a})$ ～(b) に示す. (a) は「うなぎを」が「食べ」に係って局所的な入 れ子構造を作っている意味的にも正しい解析木である。これに対して，(b) は「うなぎを」が 「行く」に係る意味的に適切でない解析木である。日本語パーザでは, 意味的に不適切な解析木 を含む複数の解析木が出力される．「行く」に関する格パターンを用いた意味解析などによって 「うなぎを」が「行く」に係らないことを判定することにより，解析木の曖昧さを絞り达み，意 味的にも正しい解析木を得ることができる.

(a) 解析例 1

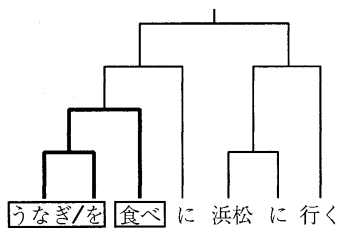

(b) 解析例 2

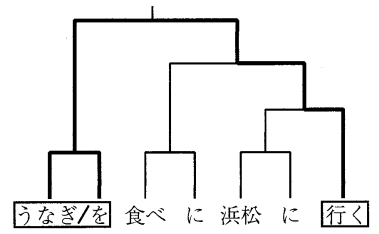

図 12 「うなぎを食べに浜松に行く」の解析木 


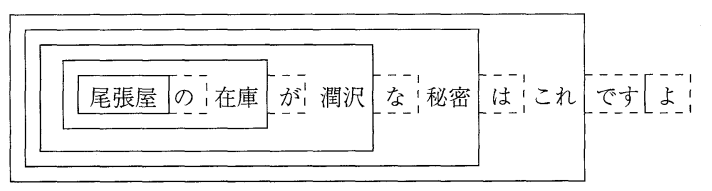

図 13 埋め込み文に形容動詞述部含む文の入れ子構造

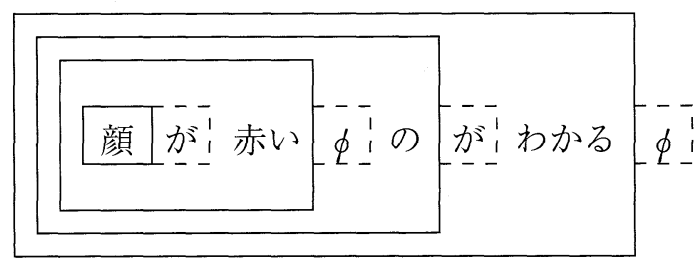

図 14 埋め込み文の被修飾名詞が形式名詞の場合

\subsection{2 埋め込み文に形容動詞述部を含む文の扱い}

「尾張屋の在庫が潤沢な秘密はこれですよ」における「潤沢十な」は，学校文法では形容動 詞語幹十形容動詞活用語尾 (連体形) であるが, 三浦文法では状態性名詞 (静詞) +肯定判断 の助動詞「た」の連体形となる.

三浦の入れ子構造では, 主体表現である助動詞は客体表現である単文全体を包み达むような 構造として表される，例文における「潤沢な」が「秘密」を連体修飾しているのではなく，「尾 張屋の在庫が潤沢」全体が「秘密」に係っているのである。このように, 意味的にも正しい構 造（図 13）を出力できる.

\subsection{3 埋め込み文の被修飾名詞が形式名詞の場合の扱い}

被修飾名詞が形式名詞（学校文法で準体助詞・終助詞とされる「の」, 学校文法で伝聞の助動 詞「そうだ」・比況の助動詞「ようた」の部分である「そう」「よう」を含む）である埋め込み 文は，図14のように文中に局所的な入れ子構造をもつ文となる.

\section{4 入れ子破りの表現の扱い}

係り受けが交差し入れ子破りが生じる場合，句構造解析では構文木が生成されない，一方， 係り受け解析では, 係り受け構造が得られるが, 係り受けの曖昧さが爆発的に増大してしまう. ここでは，係り受けの交差，すなわち入れ子破りが，陳述副詞による呼応，および単文スコー プ外への格要素の移動に伴って起こることに着目して，痕跡という考えを導入することによっ て，句構造解析風の木構造で入れ子破りに対応する方法を提案する. 


\subsection{1陳述副詞による呼応}

主体表現である陳述副詞と主体表現との呼応では入れ子破りが生じる．例えば，「本を決して 読まない」のように，主体表現である陳述副詞「決して」と否定の助動詞「ない」との呼応で は，図 $15(\mathrm{a})(\mathrm{b})$ のよう入れ子破りが生じる。ここで，陳述副詞「決して」はその係り先であ る助動詞「ない」の直前に痕跡（陳述副詞に係わる痕跡として副辞痕跡と呼ぶ）を残し，そこ から移動してきたと考える，解析では，陳述副詞をその本来の位置である副辞痕跡にあるもの として，図15(c)のような，係り受けの交差しない，入れ子構造の解析木が得られる.

\subsection{2 単文スコープ外への格要素の移動}

「うなぎを浜松に食べに電車で行った」でも図 16(a)(b) のように入れ子破りが生じる。これ は本来，動詞「行く」に係る格要素「浜松に」が動詞「行く」の単文スコープの外である，動 詞「食べる」の単文スコープ内に移動してきたことによって生じたものである，見かけ上，動 詞「食べる」の単文スコープ内にあるため，統語的には「食べる」に係るようにみえるが，意味 的には，格要素「浜松に」は直近の動詞「食べる」に係らず，後方の動詞「行く」に係る．この ような単文スコープ外への格要素の移動も入れ子破りの原因となる。このような場合, 4.4 .1 と 同様に本来，格要素があった単文スコープ内に痕跡（格要素に係わる痕跡として格要素痕跡と

(a) 係り受け解析

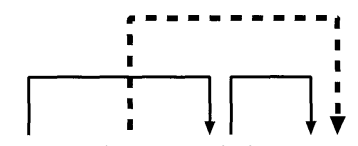

本を/決して/読ま/ない

(b) 三浦文法風

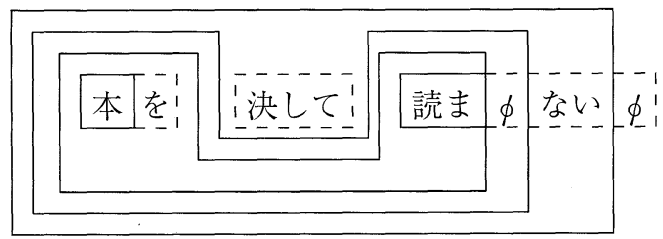

(c) 対応策

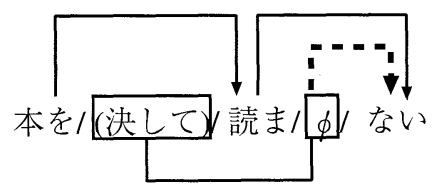

副辞痕跡

図 15 陳述副詞の呼応による入れ子破りとその対応策 
(a) 倸り受け解析

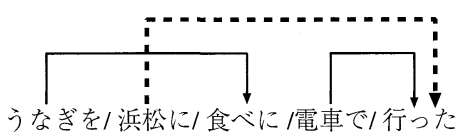

(b) 三浦文法風

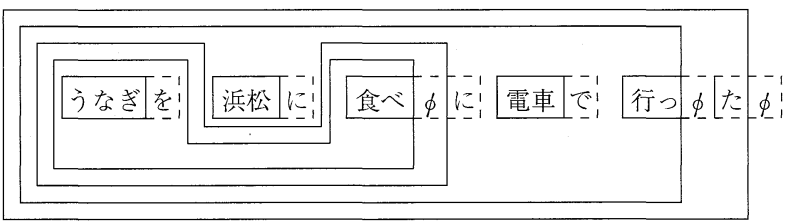

(c) 対応策

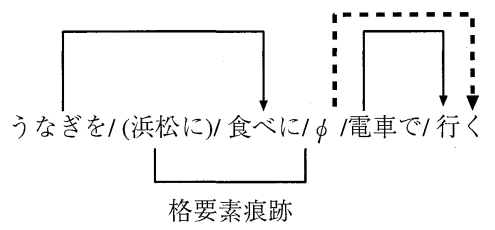

図 16 単文スコープ外への格要素の移動による入れ子破りとその対応策

呼ぶ）を残し，そこから単文スコープ外に移動してきたものと考える. 解析では，格要素をそ の本来の位置である格要素痕跡にあるものとして, 図 16(c)のような, 係り受けの交差しない, 入れ子構造の解析木が得られる。なお，すべての格要素は直近の用言の単文スコープ内にある ものとして，格要素一用言間の係り受けの可否を用言の格パターンなどを参照してチェックす る。格要素一用言間の係り受け可の場合，当該格要素は当該用言の単文スコープ内にあると判 断する，格要素一用言間の係り受け不可の場合，当該格要素は当該用言より後方にある用言の 単文スコープ内にあると判断し，当該格要素とできるだけ近い用言の単文スコープ内で当該格 要素と係り受け可となる用言をみつけ，その単文スコープ内に格要素痕跡を設定する.

\section{5 パーザへの実装と有効性の検証}

\section{1 パーザへの実装}

前節において述べた，意味と親和性のある統語構造を出力する日本語文パーザの有効性を検 証するため, 拡張型のチャートパーザ Schart(川辺, 宮崎 2005) に日本語文法規則（文法規則数 138）を実装し，日本語文パーザを試作した。

前節で示した事例に関して試作した日本語文パーザによって出力される構文木を示す．解析 結果の構文木は複数出力されるが, 記述枠組みとしての妥当性を示すために, 複数の解候補木 


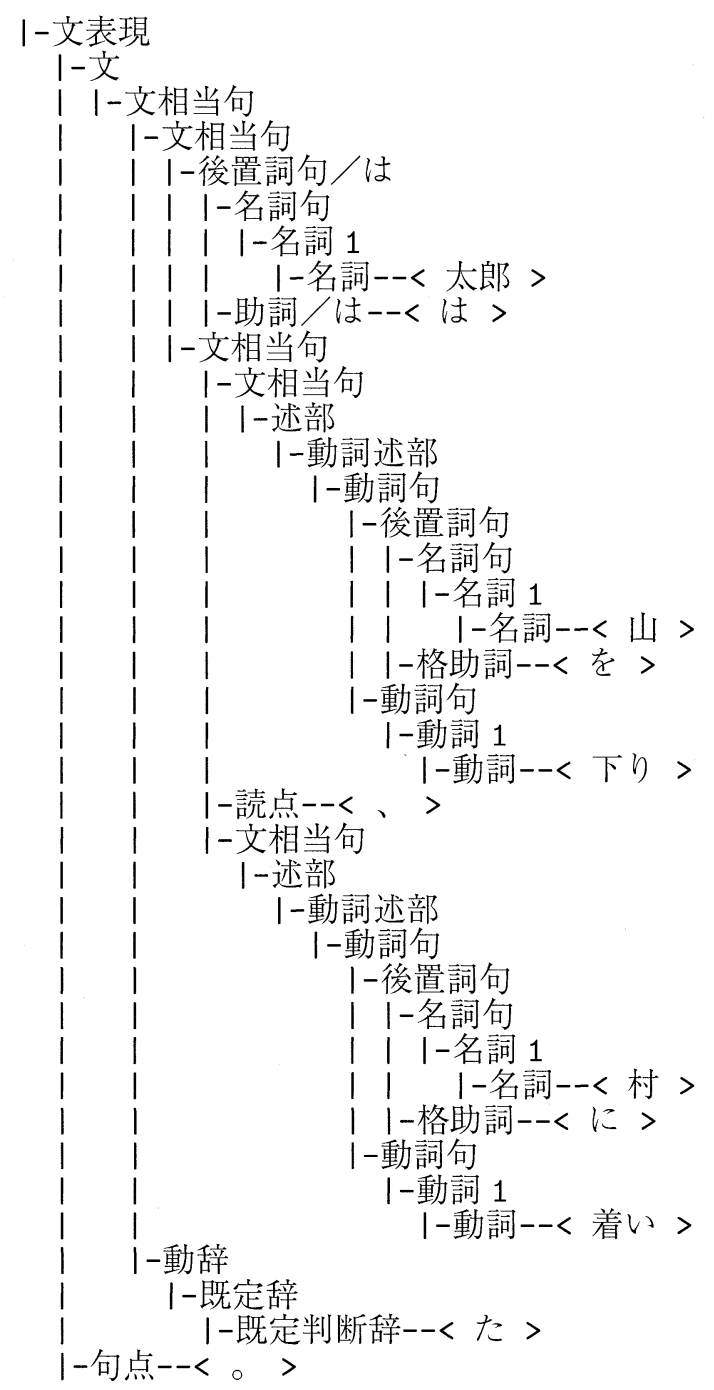

図 17 「太郎は山を下り，村に着いた.」の解析結果

の中から意味的に適切な構文木を提示する.

図 17 は「太郎は山を下り，村に着いた.」の解析結果である。一対多・多対一の係り受け関 係の例である。「太郎は」は「山を下り」と「村に着い」の両方に係り，その全体がさらに「だ」 に結びついて一つの文を作っている。

図 18 は「彼は金は無いが，アイデアはたくさん持っていた.」の解析結果である。主題の「は」 と対照の「は」の違いの例である。「金は無い」と「アイデアはたくさん持ってい」が対照の「は」 により対になり，それらに対して「彼は」が係り，最後に「た」が結び付く形となっている。 


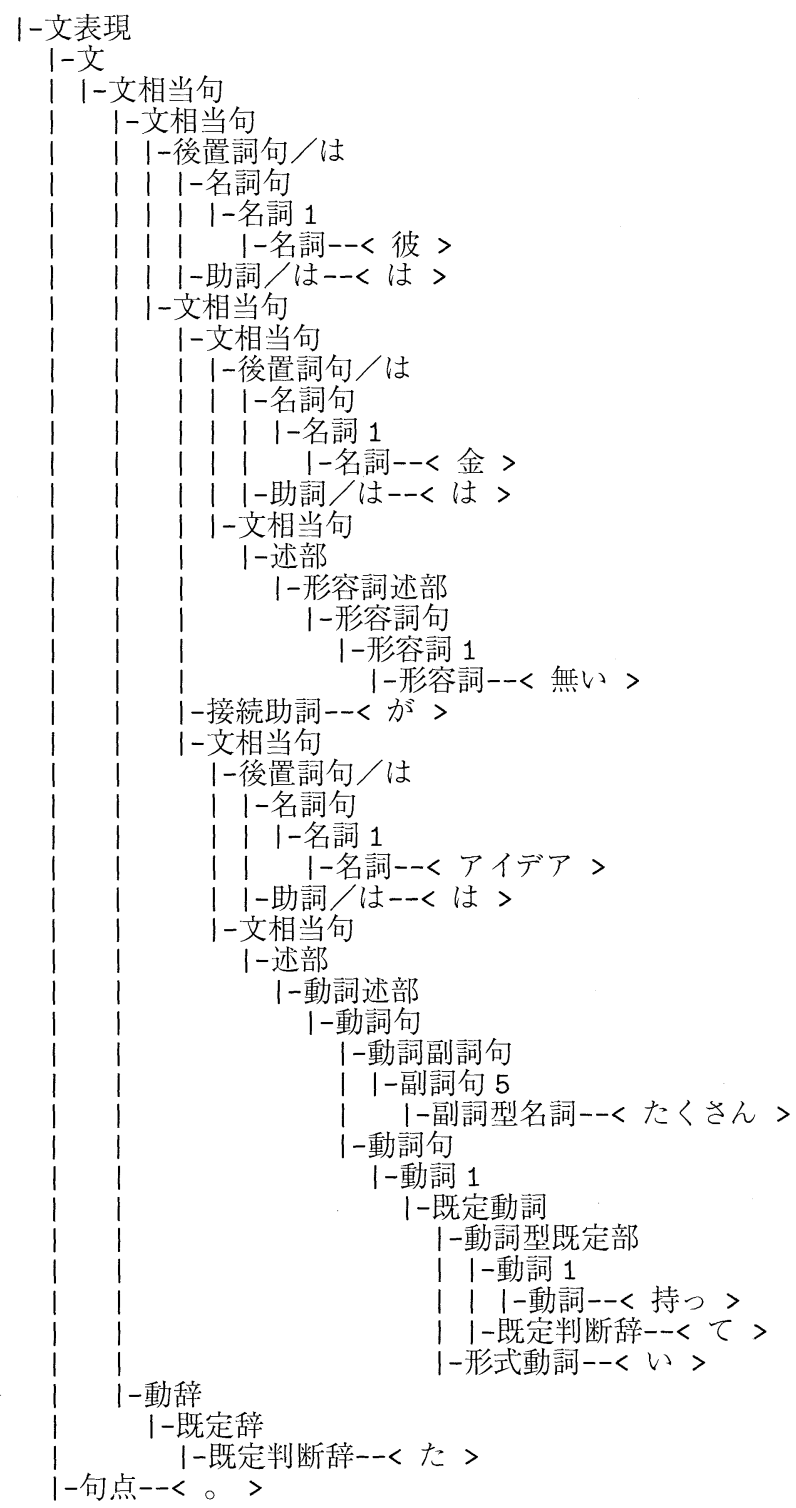

図 18 「彼は金は無いが，アイデアはたくさん持っていた.」の解析結果

困 19 は「本を読みはしない.」の解析結果である。一語が二つの品詞性を持つ場合の例であ る、連用形名詞「読み」は動詞と名詞の二つの品詞性を持つ、「読み」は，「本を」という格要 素を取る動詞としての働きと動詞「し」の格要素となる名詞としての働きをする.

図 20 は「うなぎを食べに浜松に行く.」の解析結果である。これも図 19 と同様に一語が二つ の品詞性を持つ場合の例である。「うなぎを食べ」全体が「に」に係り, 動詞「行く」の格要素 としての働きをする。 


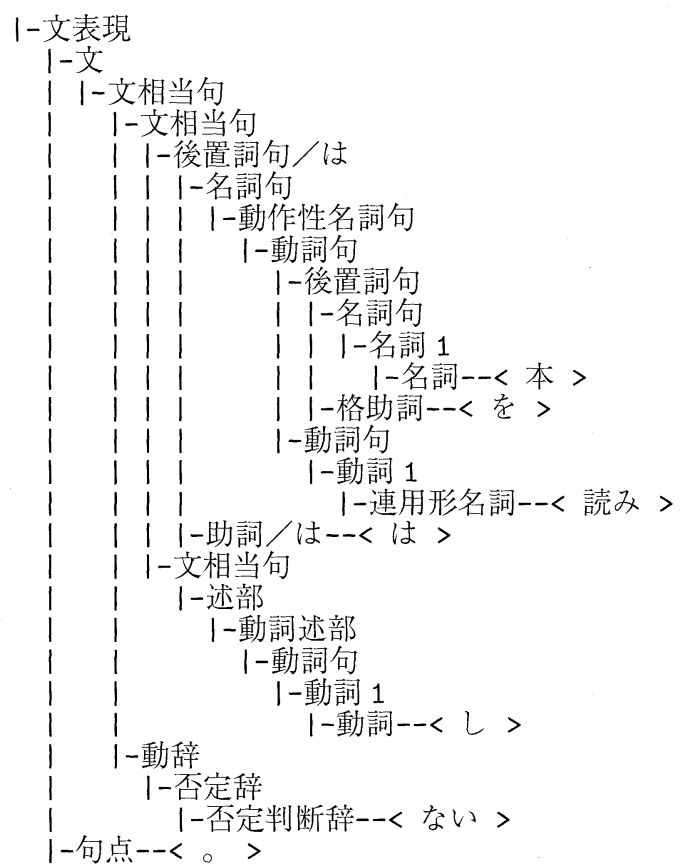

図 19 「本を読みはしない.」の解析結果

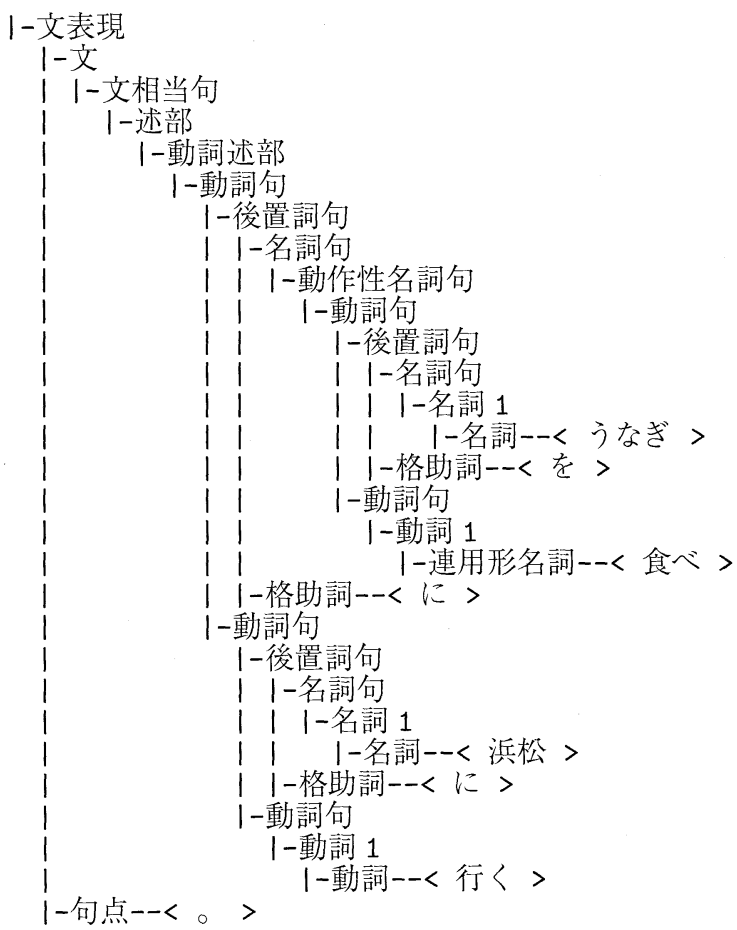

図 20 「うなぎを食べに浜松に行く.」の解析結果 
図 21 は「尾張屋の在庫が潤沢な理由はこれですよ.」の解析結果である.埋め込み文に形容動 詞述部を含む文の例である。「尾張屋の在庫が」の部分全体が「潤沢」に係る構造となっている。

図 22 は「顔が赤いのがわかる」の解析結果である. 埋め込み文の被修飾名詞が形式名詞の場 合の例である．「顔が赤い」が形式名詞「の」に係る構造となっている.

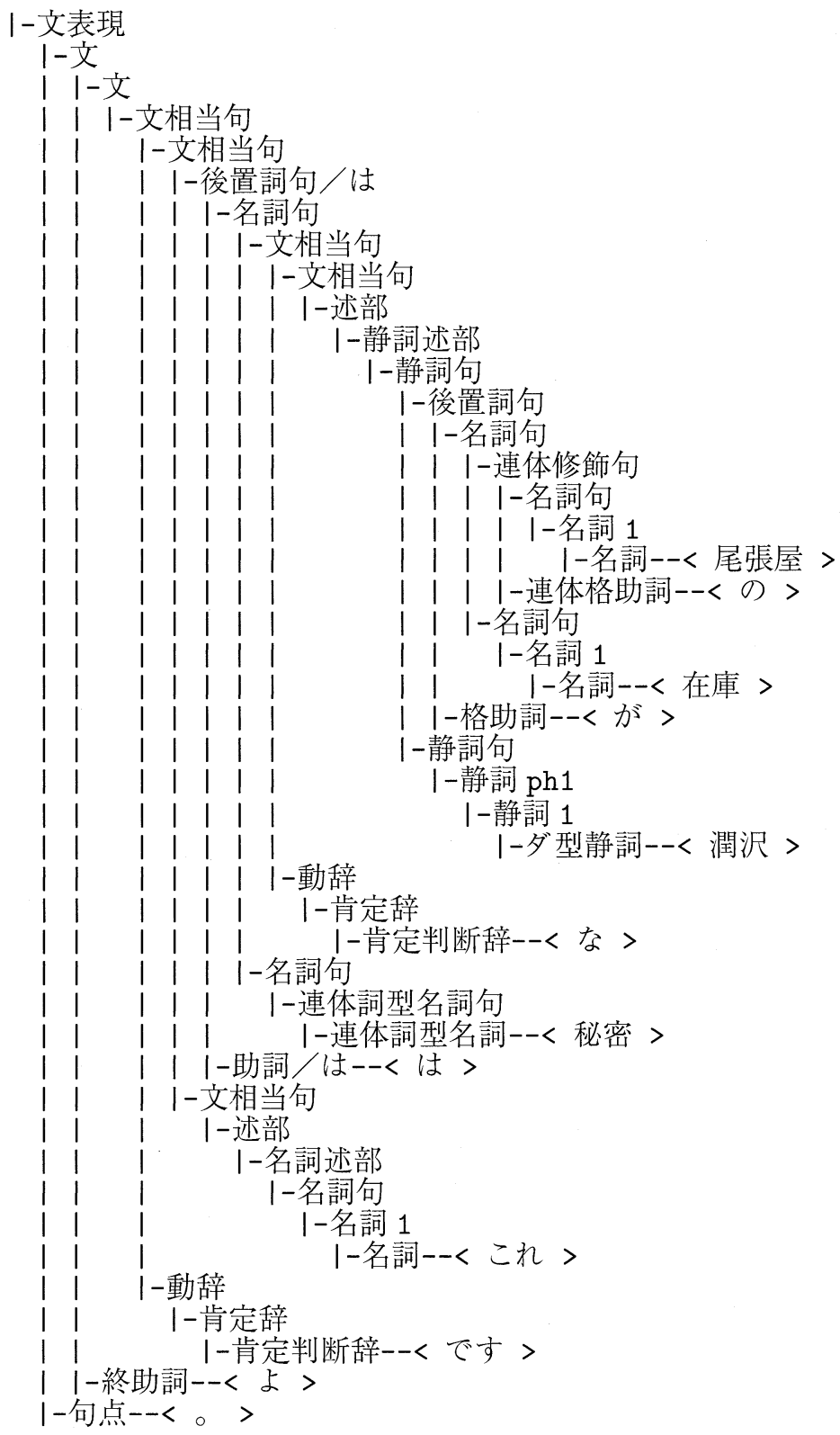

図 21 「尾張屋の在庫が潤沢な理由はこれですよ.」の解析結果 


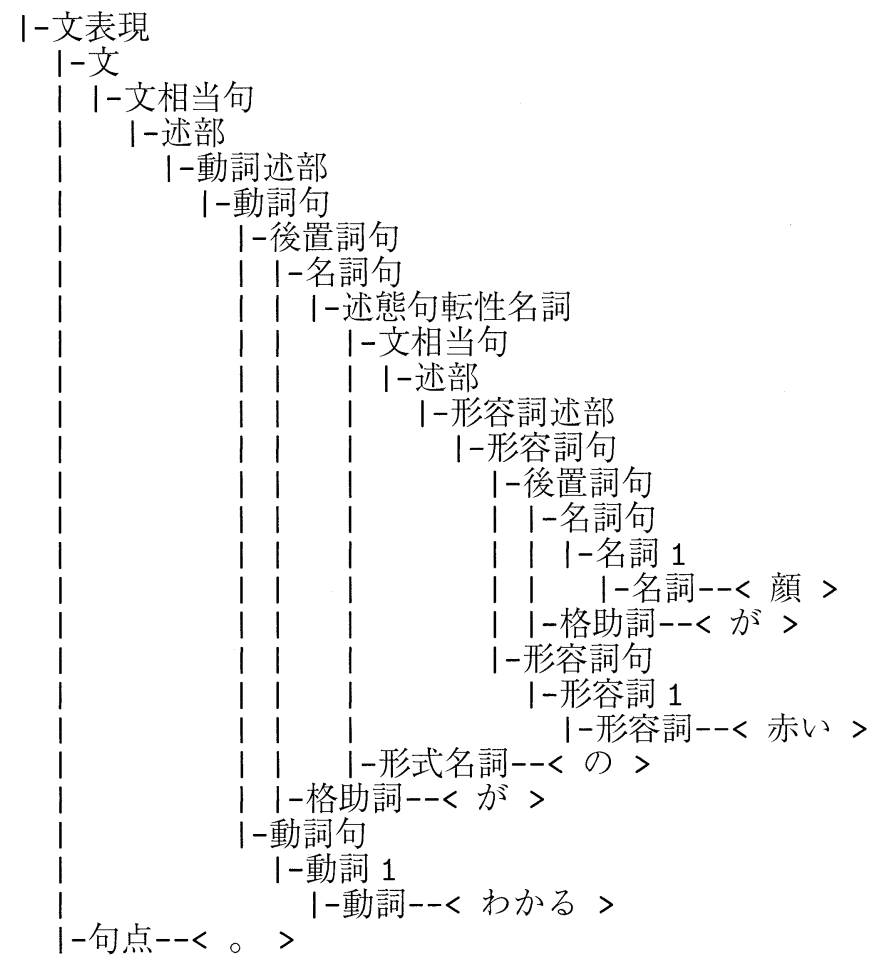

図 22 「顔が赤いのがわかる.」の解析結果

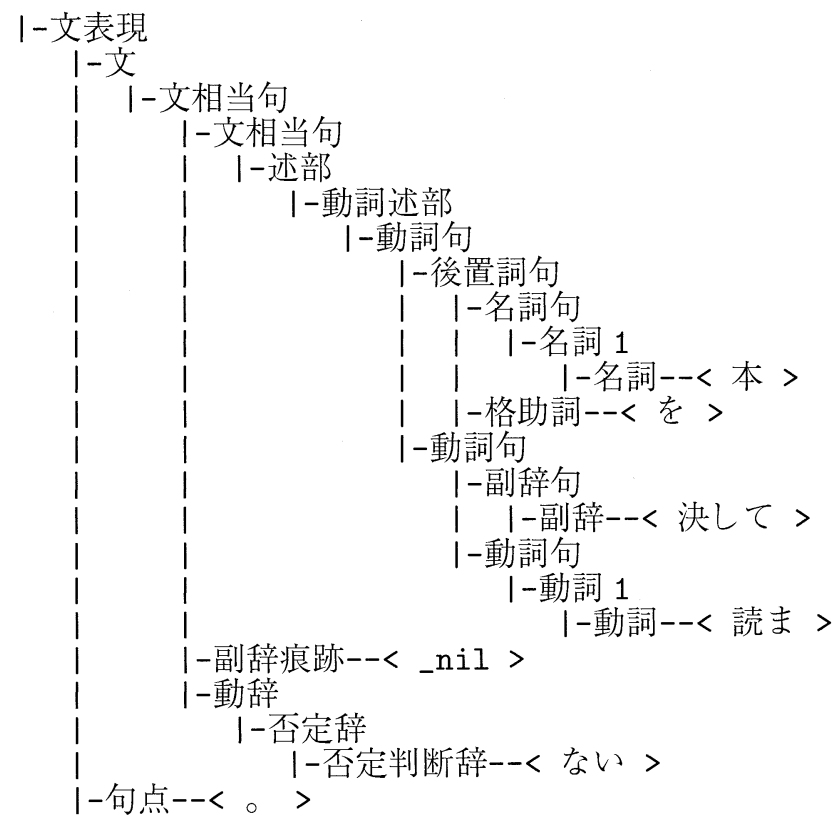

図 23 「本を決して読まない.」の解析結果 
図 23 は「本を決して読まない.」の解析結果である。この文は陳述副詞による呼応を含み，入 れ子破りが生じる。陳述副詞「決して」が意味的には「ない」に係るということを明示するた め,「ない」の直前に副辞痕跡として示す。これにより係り受け交差の問題を解消している.

入れ子破りのもう一つの例として，「うなぎを浜松に食べに電車で行った.」のように格要素 の移動が起こっている文について既に述べた。このような文では，格要素の移動を検出するた めに格パターンを利用する必要がある。本論文のパーザでは，意味的な情報をできるだけ用い ず，表層的な情報・統語的な情報を用いることを前提としている．そのため，構文解析の段階 では格要素の移動がないものとして格要素を直近の述部に掛け，意味解析の段階で格要素の移 動の検出および痕跡の表示を行う.

\section{2 日本語文パーザの有効性}

試作した日本語文パーザにおける有効性を示すため，一般的な文中にどの程度，本論文中で 示した意味との整合性が良くないパターンが存在するか，解析結果に意味的に正しい文がどの 程度含まれるかを調べた。この検証の意義は，これらの意味との整合性が良くないパターンの 出現頻度は低くないこと，および，試作した日本語文パーザが最低限の解析能力を持つことを 示すことによりパーザの有効性を示すことにある.

対象とする文は以下の通り。

- 平均文字数: 19.4 字

- 文数: 重文・複文各 50 文, 合計 100 文

- 分野: 和英辞典の例文

本論文中で述べたパターンを以下のように分類する（表 1$)$.

まず，例文中で上のタイプがどの程度存在するかを示す（表 2). 複数のタイプが該当する場 合には，複数を選択する。

さらに，例文の解析結果に意味的に正しい文がどの程度含まれるかを示す（表 3 ）。

正解含有率 $(\%)=($ 意味的に正しい解析結果を含む文数) / (形態素解析誤りを含まない文数 $) \times 100$

表 1 文の分類

\begin{tabular}{|l|l|}
\hline タイプ 1 & 一対多・多対一の係り受け関係を含む文 \\
\hline タイプ 2 & 二つの品詞性のある語を含む文 \\
\hline タイプ 3 & 埋め込み文に形容動詞述部を含む文 \\
\hline タイプ 4 & 埋め込み文の被修飾名詞が形式名詞という文 \\
\hline タイプ 5 & 陳述副詞による呼をを含む文 \\
\hline タイプ 6 & 単文スコープ外への格要素の移動を含む文 \\
\hline
\end{tabular}


表 2 例文中の各タイプの出現率

\begin{tabular}{|l|r|}
\hline \multicolumn{1}{|c|}{ タイプ } & 出現率 $(\%)$ \\
\hline \hline 1 & 6 \\
\hline 2 & 1 \\
\hline 3 & 4 \\
\hline 4 & 23 \\
\hline 5 & 4 \\
\hline 6 & 0 \\
\hline \hline いずれか & 33 \\
\hline
\end{tabular}

表 3 意味的に正しい解析結果を含む割合

\begin{tabular}{|c|r|}
\hline 文種 & 正解含有率 $(\%)$ \\
\hline \hline 重文 & 91.3 \\
\hline 複文 & 83.3 \\
\hline \hline 全体 & 87.5 \\
\hline
\end{tabular}

\section{6 むすび}

本論文では，関係意味論と三浦文法をベースとした意味と親和性のある統語構造を出力する 日本語文パーザの枠組みを提案した。さらに，日本語文パーザにその枠組みを実装し，実験を 通してその有効性を示した。これにより従来の学校文法に基づいた日本語文パーザでは意味と 親和性のある解析結果が得られない点について改善することができることを示した．今後の課 題として, 複数の解析木が得られた場合, 意味的にも正しい解析木を決定する方法について検 討する必要がある。

\section{謝 辞}

Schartパーザを提供していただいた川辺諭氏，有用な意見をいただいた新潟大学工学部情報 工学科・宮崎研究室の学生諸君に深く感謝いたします.

\section{参考文献}

池原，宮崎，白井，林 (1987). “言語における話者の認識と多段翻訳方式.” 情処論, 28 (12), pp. 1269-1279.

池原，白井 (1990). “日英機械翻訳機能試験項目の体系化.” 信学技報, NLC90-43. pp. 17-24. 池原悟 (1991). “言語表現の意味.”人工知能学会誌, 6 (2), pp. 290-291.

池原, 宮崎, 白井 (1992). “言語過程説から見た多段翻訳方式の意義. ”自然言語処理の新しい応 用シンポジウム論文集，ソフトウェア科学会／電子情報通信学会. pp. 139-140.

川辺，宮崎 (2005). “構造を含む生成規則を扱える拡張型チャートパーザーSchart パーザの実装 一.”言語処理学会第 11 回年次発表論文集. pp. 911-914. 
黒橋, 長尾 (1994). “並列構造の検出に基づく長い日本語文の構文解析.”自然言語処理, 1 (1), pp. $35-57$.

宮崎, 池原, 白井 (1992). “言語の過程的構造と自然言語処理.”自然言語処理の新しい応用シン ポジウム論文集, ソフトウェア科学会／電子情報通信学会. pp. 60-69.

宮崎，白井，池原 (1995). “言語過程説に基づく日本語品詞の体系化とその効用.”自然言語処 理, 2 (3), pp. 3-25.

水谷静夫 (1993). “意味・構文の関係を考へる九十例.”計量国語学, 19 (1), pp. 1-14.

長尾眞 (1996). “岩波講座ソフトウェア科学 15 自然言語処理.”岩波書店. pp. 180-181.

沼崎, 宮崎 (1995). “話者の対象認識過程に基づく日本語助詞「が」と「は」の意味分析とパー ザへの実装.”自然言語処理, $2(4)$, pp. 67-81.

大谷，宮田，松本 (2000). “HPSGにもとづく日本語文法について実装に向けての精緻化・拡張.” 自然言語処理, 7 (5), pp. 19-49.

三浦つとむ (1967a). 認識と言語の理論, 第一部. 勁草書房.

三浦つとむ $(1967 b)$. 認識と言語の理論, 第二部. 勁草書房.

三浦つとむ (1972). 認識と言語の理論, 第三部. 勁草書房.

三浦つとむ (1975). 日本語の文法. 勁草書房.

三浦つとむ (1976). 日本語とはどういう言語か. 講談社.

三浦つとむ (1977). 言語学と記号学. 勁草書房.

時枝誠記 (1941). 国語学原論. 岩波書店.

時枝誠記 (1950). 日本文法口語篇. 岩波書店.

\section{略歴}

武本 裕：1999 年新潟大学工学部情報工学科卒業. 2001 年新潟大学大学院自 然科学研究科博士前期課程修了. 同年新潟大学大学院自然科学研究科博士後 期課程入学. 現在に至る。日本語構文解析, 機械翻訳などの自然言語処理と その応用システムの研究に従事. 情報処理学会会員.

宮崎 正弘：1969 年東京工業大学工学部電気工学科卒業. 同年日本電信電話公 社に入社. 以来, 電気通信研究所においてコンピュータシステムの性能評価 法, 日本文音声出力システムや機械翻訳などの研究に従事. 1989 年より新潟 大学工学部情報工学科教授. 自然言語処理とその応用システムの研究に従事. 2006 年 5 月, 宮崎研究室の研究成果を活用して自然言語処理応用システムの 製品開発を行う大学発ベンチャー企業「(株) ラングテック」を設立, 代表取 締役社長を兼務. 工学博士. 1995 年日本科学技術情報センター賞 (学術賞) 
受賞. 2002 年電気通信普及財団賞（テレコム・システム技術賞）受賞. 電子 情報通信学会, 情報処理学会, 人工知能学会, 言語処理学会, 各会員.

(2006 年 3 月 2 日 受付) (2006 年 8 月 9 日 再受付) (2006 年 9 月 12 日 再々受付) (2006 年 10 月 10 日 採録) 